\title{
A Comparative Study on Regional Public Finance in China and Canada
}

\author{
a case study of Shandong Province and Nova Scotia \\ Xiaoheng $\mathrm{Xu}^{1, \text { a }}$, Paul Hobson ${ }^{2, b}$ \\ ${ }^{1}$ Shandong University of Finance and Economics, 42 Shungeng Road ,Jinan, Shandong, China \\ ${ }^{2}$ Acadia University, 15 University Ave, Wolfville, NS ,Canada \\ axiaoheng99@sdufe.edu.cn, bpaul.hobson@acadiau.ca
}

Keywords: public finance; public responsibilities and service; fiscal inequity

Abstract. This paper analyzes the administrative structure and different evolution path of public finance management of the two provinces, finds that fiscal inequity exists in both provinces regardless the political and economic background. In order to reduce the horizontal inequity, policy makers should try to make the responsibilities and finance revenue match with each other in each level of government, so as to maintain sustainable development of local economy.

\section{Introduction}

This research focused on regional public finance in China and the equivalent administrative area in Canada. We will take Shandong Province of China and Nova Scotia of Canada as Examples, to examine fiscal disparity and potential policy initiatives that would enhance regional economic development. Both of the two provinces are eastern coastal provinces and have built cooperative relationship in economy and education. Meanwhile, we also observed the unbalanced distribution of fiscal capacity and responsibility between national governments and local governments in both countries, usually the local government took too much responsibilities including education, medical treatment and infrastructure construction compared to their fiscal capacity. This paper would try to find the reasons and solutions under this phenomenon and find the different roles of local economies played in the development of the whole country.

\section{Administrative Structure Comparison}

Administrative Structure of China.Public finance is closely related to administrative structure in a country. According to the constitution, the administrative structure of China has three basic levels: Provincial, County and Township. The current existing administrative structure has four sub-national levels: Provincial, Prefectural, County and township. There are also 2 informal levels of governments below the township level called the Village level and groups.

Administrative division is one of a nation' important political policies; it has great impacts on the exploitation of resources and economic development. Along with China's economic development and urbanization, administrative divisions have changed. Shandong province located in the central part of china, as a populous province its value of agricultural production has been among the top positions of China many years. It has 17 prefectural-level cities and Jinan is the capital city like Halifax in Nova Scotia.

Administrative Structure of Canada.The administrative structure of Canada has less levels compared to China , under federal level there are three basic levels: provincial level, regional municipal level and County and district municipal level. At provincial level, there are 10 provinces (Newfoundland and Labrador, Prince Edward Island, Nova Scotia, New Brunswick, Quebec, Ontario, Manitoba, Saskatchewan, Alberta and British Columbia) and 3 territories (Yukon, Northwest Territories and Nunavut). The major difference between a Canadian province and a territory is that provinces receive their power and authority from the Constitution Act, 1867 (formerly called the British North America Act, 1867), whereas territorial governments have powers delegated to them by the federal government. 
In Nova Scotia, there are three Regional municipalities: Halifax Regional Municipality (HRM), Cape Breton Regional Municipality (CBRM) and Queen's Regional Municipality (Queens). Below regional municipals, there are 31 Towns.

\section{Public Finance Comparison}

Basic Situation of Public Finance in China.The public finance budgetary system consists 4 parts: National General Public Budget, National Government-managed Funds Budget, National State Capital Operations Budget and Social Security Fund Budget. The last three are special funds. So in this research we mainly focus on National General Public Budget which is directly related to public finance and public service. There is a two-level budgetary system in China: Central Government's General Public Budget and Local Governments' General Public Budget Revenue. Table 1 shows the changes of national general government revenue and expenditure along with GDP in the last 5 years.

Table 1: General National Government Budget and GDP

\begin{tabular}{|c|c|c|c|c|c|}
\hline & 2014 & 2013 & 2012 & 2011 & 2010 \\
\hline $\begin{array}{c}\text { General government revenue ( } \\
\text { billion yuan) }\end{array}$ & 14037.00 & 12920.96 & 11725.35 & 10387.44 & 8310.15 \\
\hline $\begin{array}{c}\text { General government } \\
\text { expenditure (billion yuan) }\end{array}$ & 15178.56 & 14021.21 & 12595.30 & 10924.78 & 8987.42 \\
\hline Growth rate of revenue & $8.60 \%$ & $10.20 \%$ & $12.90 \%$ & $25 \%$ & $21.30 \%$ \\
\hline Growth rate of expenditure & $8.30 \%$ & $11.30 \%$ & $15.30 \%$ & $21.60 \%$ & $17.80 \%$ \\
\hline Per Capita Revenue (yuan) & 10262.32 & 9495.68 & 8659.53 & 7709.54 & 6197.40 \\
\hline Per Capita Expenditure (yuan) & 11096.90 & 10304.26 & 9302.01 & 8108.35 & 6702.48 \\
\hline GDP(billion yuan) & 63591 & 58801.88 & 53412.3 & 48412.35 & 40890.3 \\
\hline GDP per capita(yuan) & 46629 & 43320 & 39544 & 36018 & 30567 \\
\hline Proportion of Revenue in GDP & $22.07 \%$ & $21.97 \%$ & $21.95 \%$ & $21.46 \%$ & $20.32 \%$ \\
\hline $\begin{array}{c}\text { Proportion of Expenditure in } \\
\text { GDP }\end{array}$ & $23.87 \%$ & $23.84 \%$ & $23.58 \%$ & $22.57 \%$ & $21.98 \%$ \\
\hline The revenus & & &
\end{tabular}

The revenues do not include government debts; expenditures include interest payments of government debts.

Source: National Bureau of Statistics of the People's Republic of China, http://www.stats.gov.cn/

From the above table we can see that national general government revenue and expenditure increased along with GDP in the last 5 years, while the growth rate of both variables decreased. Government budget increased faster than GDP, the proportion of revenue in GDP increased from 20.32\% to $22.07 \%$, and the proportion of expenditure in GDP increased from $21.98 \%$ to $23.87 \%$.

The Economic Position of Shandong Province in China. Shandong province is a big agricultural province with large population. It has occupied an increasingly important position in the economic operation and development of China. Table 5 showed the basic and detailed information of the local government revenues and expenditures of Shandong province in the last 5 years. From the table we can see that local government revenue and expenditure increased along with GDP in the last 5 years, while the gap between government expenditure and revenue is always existing. 
Table 2: The economic position of Shandong province in China

\begin{tabular}{|c|c|c|c|c|c|}
\hline & 2014 & 2013 & 2012 & 2011 & 2010 \\
\hline GDP $^{1}$ & $9.35 \%$ & $9.39 \%$ & $9.36 \%$ & $9.37 \%$ & $9.58 \%$ \\
\hline Population & $7.16 \%$ & $7.12 \%$ & $7.08 \%$ & $7.05 \%$ & $7.01 \%$ \\
\hline Revenue & $3.58 \%$ & $3.53 \%$ & $3.46 \%$ & $3.33 \%$ & $3.31 \%$ \\
\hline Expenditure & $4.73 \%$ & $4.77 \%$ & $4.69 \%$ & $4.58 \%$ & $4.61 \%$ \\
\hline
\end{tabular}

Source: National Bureau of Statistics of the People's Republic of China, http://www.stats.gov.cn/

Table 2 gives us some important information, the population of Shandong province accounts for $7 \%$ in the whole country while it contributes more than $9 \%$ of the national GDP. Government revenue of Shandong province only account for 3.31\%- 3.58\% of National Government revenue during the five years 2011-2014, and Government expenditure of Shandong province account for $4.58 \%-4.73 \%$ of National Government expenditure. Government revenue could not cover government expenditure is a long term problem in Shandong province. Mean while the uneven distribution of government revenue and expenditure might raise some problems in the province in taking its public responsibilities and providing public services to the residents.

Basic Situation of Public Finance in Canada. The economic size of Canada in the year 2014 was $1,973,043$ millions of dollars at that year's prices, that is approximately 9,865 billion RMB compared to China's 63,591 billion RMB yuan. The total fiscal burden in Canada was $\$ 15,872$ per capita in 2014, and it was $\$ 14,027$ in 2008 . The fiscal burden is a commonly used fiscal indicator derived from the Government Finance Statistics framework. Total provincial-territorial and local governments (PTLGs) fiscal burden increases in every province and was $\$ 8,662$ per capita in 2014 . The fiscal burden per capita increased in every province over the period, with Nova Scotia recording the second largest gains, that is $\$ 1,579$ per capita ${ }^{2}$.

The economic position of Nova Scotia in Canada. Nova Scotia was a traditionally resource-based province and now its economy has diversified in resource, agriculture, tourism, film industry, manufacturing and Information \& Communication Technology. Different from Shandong province, Nova Scotia produced less GDP with its comparatively large population proportion. See table 3.

Table 3: The economic position of Nova Scotia in Canada

\begin{tabular}{|c|c|c|c|c|c|}
\hline & 2014 & 2013 & 2012 & 2011 & 2010 \\
\hline GDP $^{3}$ & $1.98 \%$ & $2.04 \%$ & $2.08 \%$ & $2.13 \%$ & $2.22 \%$ \\
\hline Population & $2.65 \%$ & $2.68 \%$ & $2.72 \%$ & $2.75 \%$ & $2.76 \%$ \\
\hline
\end{tabular}

Source: Statistics Canada, http://www.statcan.gc.ca/eng/start

\section{Comparison of Public Finance Issues}

Recent structure of municipal government and public finance system started from the land mark Graham Commission Report, then followed by the important Service Exchange initiative and the regional amalgamations in Halifax, Cape Breton and Queen's and the subsequent Roles and Responsibilities.

\footnotetext{
${ }^{1}$ GDP in the table means the proportion of this variable in the whole country, so does the other three variables population,revenue and expenditure.

${ }^{2}$ All the data in this section are from statistics Canada, http://www.statcan.gc.ca/eng/start

${ }^{3}$ GDP in the table means the proportion of this variable in the whole country, so does the other variable population.
} 
A core recommendation of the Graham Commission was the implementation of a municipal equalization grant in Nova Scotia. While municipal structure is an area of provincial jurisdiction under the constitution, broad equity principles are outlined in the constitution which are binding on both the federal and provincial governments. Accordingly, provinces are bound by these same principles in designing municipal structures. Unfortunately, the Service Exchange initiative was driven more by fiscal neutrality considerations than by fundamental principles. Nonetheless, in the period since the Service Exchange initiative was first introduced, Nova Scotia has moved in the direction of a municipal structure that does conform to fundamental principles. In particular, the Graham Commission had called for a separation between local services - those that are of primarily local benefit and should, accordingly, be provided by municipalities and general services - those that are of more general benefit to the Province and should, accordingly, be provided by the Province. The Service Exchange initiative broadly conformed to this division in principle. In practice, however, it failed, in part because it did not include appropriate funding arrangements. And the emphasis on fiscal neutrality compromised the whole exercise. Fiscal decentralization to the local level invariably leads to different municipalities having different fiscal capacities. That is, they cannot provide standard levels of public services at given tax rates to their residents. This gives rise to a horizontal inequity, so-called, fiscal inequity.

In Shandong Province as well as in China, fiscal inequity is also a big problem, especially in rural areas. People mainly concerns about the basic public services like infrastructure, compulsory education, social security and health. Due to the long-term urban and rural dual management system, the supply structure of public services is not balanced, basic public service level in rural areas is far lower than that in cities, and basic public services provided in the eastern part are significantly higher than in the western both in quantity and quality. Although both live and work in cities, migrant workers could not enjoy the same public services as urban residents. The fiscal inequity restricts the development of the social economy and residents living standards. After many years of fiscal and taxation reform, the situation has been improved a lot. But still there is a long way to go in the aim of fiscal equity.

\section{Conclusions}

Based on the analysis, we can see that although have different administrative structure and different evolution path of public finance management, fiscal inequity exists in both provinces. In order to reduce the horizontal inequity, policy makers should try to make the responsibilities and finance revenue match with each other in each level of government, the Provinces should ensure that municipalities have access to the broad property tax powers and revenues sufficient to finance their spending responsibilities to maintain a sustainable development.

\section{Acknowledgments}

This work was financially supported by 2015 Joint Research Program of Shandong University of Finance and Economics and Dalhousie University .

\section{References}

[1]Graham Royal Commission report and the future of Halifax-Dartmouth : papers from a series of nine public discussions, January 7-March 4, 1975. Halifax [N.S.] : Institute of Public Affairs, Dalhousie University, 1975.

[2]Jing Ma, Realistic Problems and Fiscal Countermeasures of Public Service Supply in Urban-Rural Fringe Areas-Based on a Survey in Shandong Province, [J] Public Finance Research, 2013(3):41-45.

[3]Murray Beck, The Evolution of Municipal Government in Nova Scotia, 1749-1973 (a study prepared for the Graham royal commission, 1973).

[4]Murray Beck, The Government of Nova Scotia , Toronto, University of Toronto Press, 1957

[5] Xinli Li, Research on Fiscal Policy of Infrastructure Supply in Urban-Rural Fringe Areas -from the Perspective of Public Service Equalization, [D]Central University of Finance and Economics, 2012. 
[6] Dejuan Wang, Research on Fiscal policy of public service equalization in agricultural and pastoral areas, [J]China State Finance,2008(21):47-48. 